\title{
Deteksi Cacat Bantalan Poros Engkol Motor Pembakaran dalam Menggunakan Spektrum Envelope
}

\author{
(Detection of Faulty Crank Shaft's Bearing Using Envelope Spectrum) \\ Berli Paripurna Kamiel ${ }^{\mathrm{a}}$ \\ ${ }^{\text {aP }}$ rogram Studi Teknik Mesin, Fakultas Teknik, Universitas Muhammadiyah Yogyakarta \\ Jalan Brawijaya, Tamantirto, Kasihan, Bantul, DI Yogyakarta, Indonesia, 55183 \\ e-mail: berlikamiel@umy.ac.id
}

\begin{abstract}
Abstrak
Bantalan poros engkol adalah salah satu komponen penting pada motor pembakaran-dalam (IC engine) yang dapat mengalami cacat akibat pembebanan berulang dan temperatur tinggi. Kerusakan bantalan menyebabkan penurunan kinerja mesin yang jika tidak segera dilakukan tindakan perawatan dapat mengakibatkan kerusakan total. Analisis spektrum getaran adalah teknik utama yang digunakan untuk mendeteksi cacat bantalan. Namun demikian, spektrum tidak efektif untuk mendeteksi cacat bantalan di mesin-mesin pembakaran-dalam karena menghasilkan background noise yang sangat besar sehingga menutup amplitudo getaran bantalan. Penelitian ini mengusulkan prosedur pre-processing sinyal getaran untuk mengeliminasi frekuensi-rendah-amplitudo-tinggi dan menguatkan amplitudo dari frekuensi bantalan. Penelitian ini menerapkan analisis envelope pada bantalan poros engkol motor pembakaran dalam 2 langkah. Eksperimen pada rig uji menggunakan 3 kondisi bantalan single row dari Danmotor yaitu bantalan normal (tidak cacat), cacat lintasan dalam ukuran 0,25 mm dan 0,50 $\mathrm{mm}$. Kecepatan poros dijaga konstan pada variasi 1500 RPM dan 2000 RPM. Sensor akselerometer diletakkan pada blok mesin dekat dengan lokasi poros engkol untuk merekam sinyal getaran menggunakan kecepatan sampling 51200 $\mathrm{Hz}$. Hasil penelitian menunjukan bahwa spektrum tidak dapat mendeteksi cacat bantalan untuk semua ukuran cacat dan kecepatan poros sedangkan spektrum envelope berhasil menampilkan BPFI dan side band yang dapat digunakan untuk mendeteksi cacat bantalan dan menentukan level cacatnya.
\end{abstract}

Kata kunci: Bantalan, Poros Engkol, Motor Pembakaran Dalam, Spektrum Envelope, Akselerometer

\begin{abstract}
A bearing on the crankshaft is one of critical component of the IC engine which may fault due to cyclic loading and high temperature. The vibration spectrum analysis is the main technique used to detect faulty bearings. However, it is not effective because IC engine produces a very large background noise which immerses bearing vibration amplitude. The study proposes a signal pre-processing procedure to eliminate low-frequency high-amplitude vibration and magnifies the amplitude of the bearing frequency. This paper applies envelope analysis on crankshaft bearings of two-strokes IC engine. The experiments on the test rig uses 3 condition of single row bearing from Danmotor i.e. normal bearing (healthy), inner race fault of $0,25 \mathrm{~mm}$ and $0,50 \mathrm{~mm}$. The shaft speed of 1500 RPM and 2000 RPM is used during experiment. An accelerometer sensor is placed on the engine block near the location of the crankshaft to record vibration signals using $51200 \mathrm{~Hz}$ sampling rate. The result shows that spectrum fails to detect faulty bearing for all size defects and shaft speed. Meanwhile, envelope spectrum shows obvious BPFI and its side bands which can be used to detect and localize bearing fault.
\end{abstract}

Keywords: Bearing, Crank Shaft, IC Engine, Envelope Spectrum, Accelerometer 


\section{Pendahuluan}

Motor pembakaran dalam atau internal combustion engine (IC engine) umum digunakan sebagai penggerak kendaraan penumpang yang bekerja dengan prinsip mengkonversi gerak translasi torak menjadi gerak rotasi poros engkol (crank shaft). Gerakan rotasi poros engkol ditumpu oleh sebuah bantalan yang menerima beban relatif besar dan bersifat periodik. Kondisi ini menyebabkan bantalan berangsur-angsur mengalami degradasi atau cacat yang dapat menurunkan kinerja mesin.

Cacat bantalan menghasilkan frekuensi yang besarnya tergantung pada lokasi cacat, kecepatan poros dan geometri bantalan. Frekuensi bantalan cacat menghasilkan amplitudo tinggi pada spektrum yang merefleksikan energi impak hasil benturan antara lokasi cacat dengan elemen gelinding bantalan [1].

Namun demikian, deteksi bantalan cacat menggunakan spektrum tidak mudah diamati jika cacat tersebut berada pada kondisi awal (early fault) karena energi impak akibat benturan antara lokasi cacat dengan elemen gelinding sangat kecil. Energi yang kecil tersebut pada spektrum akan tersebar di bentang frekuensi lebar (broadband) sehinga amplitudonya sangat rendah dan terbenam di dalam amplitudo noise dan amplitudo elemen mesin lainnya [2].

Kemampuan spektrum dalam mendeteksi bantalan cacat awal semakin rendah pada bantalan di motor pembakaran dalam karena motor pembakaran dalam menghasilkan impuls yang besar akibat ledakan pada ruang bakar yang terjadi pada setiap langkah kerja [3]. Impuls pada spektrum akan menghasilkan amplitudo kontinyu bukan diskrit yang artinya energi spektrum tersebar secara kontinyu sepanjang bentang frekuensi alih-alih terpusat pada frekuensi tertentu [4]. Hal ini menyebabkan observasi amplitudo frekuensi bantalan cacat semakin sulit dilakukan.

Kelemahan spektrum dapat diatasi dengan menggunakan teknik analisis envelope yang pada dasarnya melakukan pre-processing sinyal baku (raw signal) sebelum proses transformasi ke dalam domain frekuensi menggunakan Fast Fourier Transform (FFT). Tiwari dan Jatola [5] melaporkan efektivitas analisis envelope dalam mendeteksi bantalan bola cacat lintasan luar. Elemen piezoelektrik digunakan untuk merekam sinyal baku dilanjutkan dengan proses band pass filtering, demodulasi, dan FFT. Spektrum envelope menunjukkan puncak amplitudo yang jelas dan mudah diobservasi pada frekuensi cacat lintasan luar. Penelitian lain yang dilakukan oleh Hochmann dan Bechhoefer [6] menunjukkan bahwa analisis envelope efektif mendeteksi bantalan cacat awal pada sistem transmisi helikopter dengan mengekstrak parameter cacat dari modulasi sinyal getaran. Betea dkk. [7] menyimpulkan bahwa transformasi Hilbert adalah metode demodulasi sinyal paling baik dalam mendeteksi envelope sinyal getaran.

Walaupun analisis envelope terbukti efektif mendeteksi bantalan cacat awal, tetapi tidak ditemukan penelitian yang menunjukkan bahwa metode ini juga efektif dalam mendeteksi bantalan cacat pada motor pembakaran dalam. Pendekatan yang banyak dilakukan pada motor pembakaran dalam adalah berdasarkan metode pengenalan pola atau machine learning [8] yang membutuhkan jumlah data yang banyak dan kondisi benchmark ketika prasyarat ini tidak selalu tersedia dalam praktik di lapangan. Penelitian ini mengusulkan preprocessing sinyal baku getaran menggunaan analisis envelope untuk mendeteksi bantalan cacat pada poros engkol motor pembakaran dua langkah.

\section{Metode}

Bantalan cacat menghasilkan getaran dengan frekuensi yang sebanding dengan kecepatan poros. Cacat pada bantalan dapat terjadi pada lokasi lintasan dalam (inner race), lintasan luar (outer race), elemen bola (ball fault), dan elemen sangkar (cage fault).

Informasi terkait cacat yang terjadi pada lintasan luar ditunjukkan dengan adanya frekuensi eksitasi impuls yang disebut dengan Ball Pass Frequency Outer Race (BPFO) dan dapat dihitung dengan persamaan (1). Persamaan (2) untuk Ball Pass Frequency Inner Race (BPFI), Persamaan (3) untuk cacat elemen bola, Ball Spin Frequency (BSF), dan Persamaan (4) untuk cacat sangkar, Fundamental Train Frequency (FTF). 


$$
\begin{aligned}
& B P F O=\frac{N b}{2} \times f r \times\left(1-\frac{d b}{d p} \times \cos \alpha\right) \\
& B P F I=\frac{N b}{2} \times f r \times\left(1-\frac{d b}{d p} \times \cos \alpha\right) \\
& B S F=\frac{N b}{2} \times f r \times\left(1-\frac{d b}{d p} \times \cos \alpha\right) \\
& F T F=\frac{N b}{2} \times f r \times\left(1-\frac{d b}{d p} \times \cos \alpha\right)
\end{aligned}
$$

keterangan:

$\mathrm{Nb}=$ Jumlah bola

$\mathrm{fr} \quad=$ Frekuensi relatif antara lintasan luar dan lintasan dalam $(\mathrm{Hz})$.

$\mathrm{db}=$ Diameter bola $(\mathrm{mm})$.

$\mathrm{dp}=$ Diameter pitch $(\mathrm{mm})$.

$\alpha \quad=$ Sudut kontak (derajat).

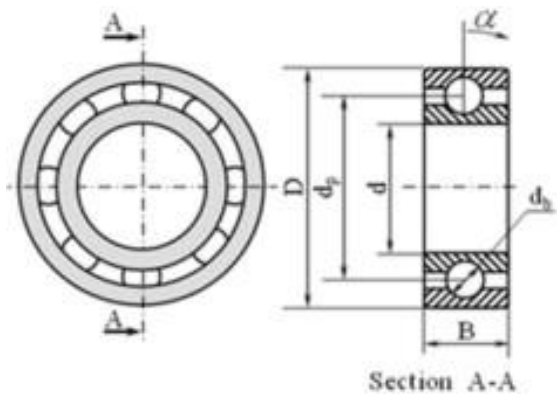

Gambar 2.1. Bantalan bola

Objek utama penelitian ini adalah getaran dari rig uji mesin motor Vespa dua langkah. Sebuah akselerometer diletakkan menggunakan sepatu magnet pada blok mesin sedekat mungkin dengan lokasi bantalan yang diobservasi pada arah radial. Sinyal getaran direkam menggunakan istrumen data akuisisi yang diteruskan ke sebuah komputer melalui kabel USB. Perekaman sinyal getaran dimulai setelah mesin dinyalakan selama 1 menit untuk mendapatkan kondisi steady. Durasi perekaman adalah 20 detik dan diulang sebanyak 30 kali dengan jeda antarrekaman sebesar 3 detik. Hal ini dilakukan untuk memastikan rekaman sinyal getaran mengandung cukup informasi keseluruhan dinamika mesin. Frekuensi sampling di-set sebesar $51200 \mathrm{~Hz}$.

Tiga kondisi bantalan poros engkol yaitu kondisi normal (tidak cacat), cacat ringan, dan cacat lanjut digunakan pada penelitian ini dengan variasi kecepatan poros engkol 1500 RPM dan 2000 RPM. Bantalan yang digunakan ditunjukkan pada Gambar 2.2 adalah merk Danmotor dengan diameter dalam $25 \mathrm{~mm}$, diameter luar $62 \mathrm{~mm}$, dan jumlah bola 8. Cacat bantalan dibuat dengan menggores lintasan dalam menggunakan mesin EDM dengan dimensi lebar 0,25 $\mathrm{mm}$ untuk cacat ringan dan lebar 0,50 $\mathrm{mm}$ untuk cacat lanjut.
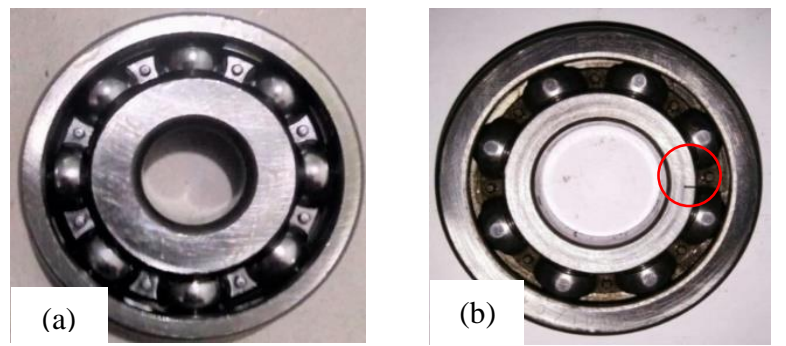

Gambar 2.2. Bantalan (a) normal (tidak cacat), (b) cacat 
Secara skematis, perekaman data dari rig uji menggunakan sistem data akuisisi dapat dilihat pada Gambar 2.3.

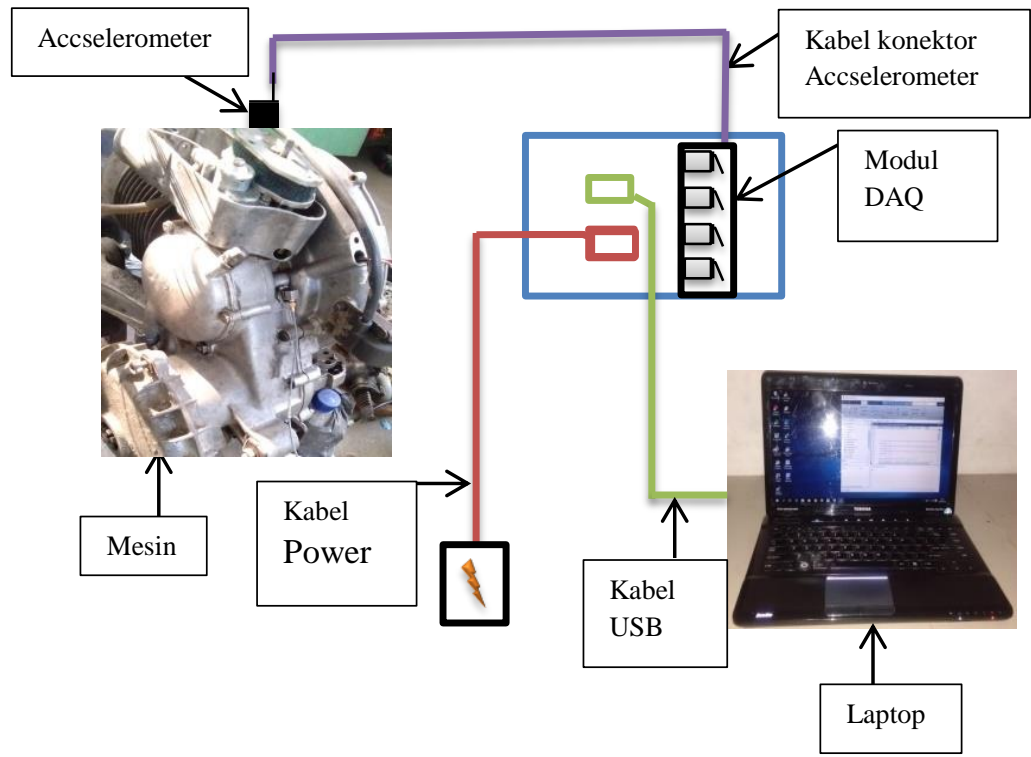

Gambar 2.3. Skema rig uji

Analisis envelope mengekstrak impak periodik getaran yang terjadi pada bantalan. Prosedur pemrosesan sinyal menggunakan analisis envelope ditunjukkan pada Gambar 2.4. Sinyal getaran domain waktu difilter menggunakan high pass band filter. Proses pemfilteran ini akan menghilangkan komponen frekuensi rendah yang umum dijumpai pada mesinmesin rotari, seperti frekuensi poros, frekuensi misalignment, dan unbalance. Setelah difilter sinyal, kemudian dikoreksi dengan proses enveloping, bagian bawah (negatif) sinyal domain waktu dilipat ke bagian atas (positif) sehingga hasilnya tampak seluruh sinyal berada di atas sumbu referensi [9]. Proses enveloping dilakukan dengan transformasi Hilbert dan selanjutnya ditransformasikan sekali lagi menggunakan FFT untuk mendapatkan spektrum envelope. Keseluruhan proses tersebut akan mengeliminasi semua komponen frekuensi yang tidak terkait dengan frekuensi yang diakibatkan impak seperti frekuensi poros, misalignment, dan unbalance.

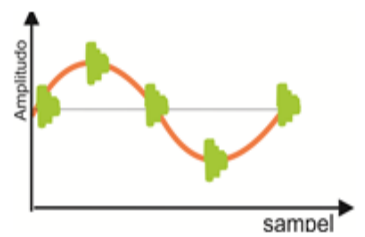

Raw signal/Time Domain

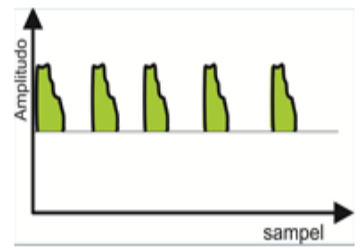

Envelope

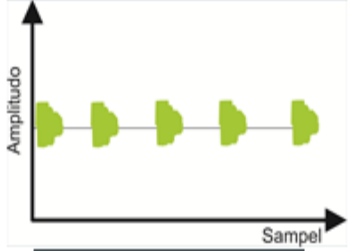

High pass filter

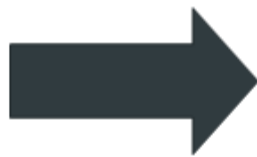

FFT

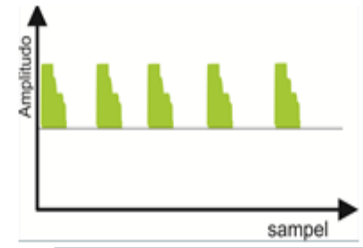

Hilbert Transform

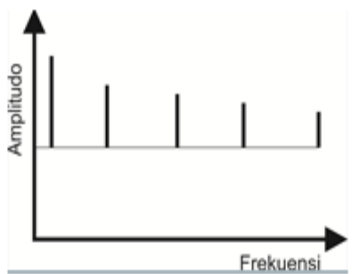

Spektrum Envelope

Gambar 2.4. Skema proses envelope 


\section{Hasil dan Pembahasan}

Gambar 3.1 adalah domain waktu dan domain frekuensi pada kecepatan poros 1500 RPM, sedangkan Gambar 3.2 adalah domain waktu dan domain frekuensi kecepatan 2000 RPM. Berturut-turut pada Gambar 3.1 (a), (b), dan (c) adalah domain waktu bantalan normal, cacat $0,25 \mathrm{~mm}$ dan cacat $0,50 \mathrm{~mm}$ yang menunjukkan peningkatan amplitudo sejalan dengan peningkatan ukuran besar cacat. Peningkatan amplitudo disebabkan oleh peningkatan energi impak benturan antara lokasi cacat dengan elemen gelinding bantalan. Ukuran cacat yang lebih besar akan menghasikan impak yang lebih besar. Walaupun terdapat perbedaan amplitudo yang besar pada domain waktu, jenis cacat yang terjadi tidak dapat ditentukan. Spektrum bantalan cacat pada Gambar 3.1 (e) dan (f) menunjukkan amplitudo tinggi hanya terlihat pada frekuensi poros (fo) sebesar $25 \mathrm{~Hz}$, tetapi tidak terlihat pada frekuensi bantalan cacat yang besarnya dapat dilihat pada Tabel 3.1. Frekuensi bantalan cacat lintasan dalam dihitung menggunakan persamaan 2. Domain waktu dan domain frekuensi yang hampir sama juga diperoleh pada kecepatan poros 2000 RPM seperti dapat dilihat pada Gambar 3.2.

Spektrum pada Gambar 3.1 dan Gambar 3.2 tidak berhasil mendeteksi frekuensi bantalan cacat lintasan dalam karena amplitudo impak akibat cacat relatif sangat kecil jika dibandingkan amplitudo getaran akibat dari siklus pembakaran. Kesulitan mendeteksi amplitudo dari frekuensi bantalan cacat sering dijumpai pada kasus-kasus di motor pembakaran dalam dan mesin-mesin rotari lainnya yang memiliki background noise relatif besar.
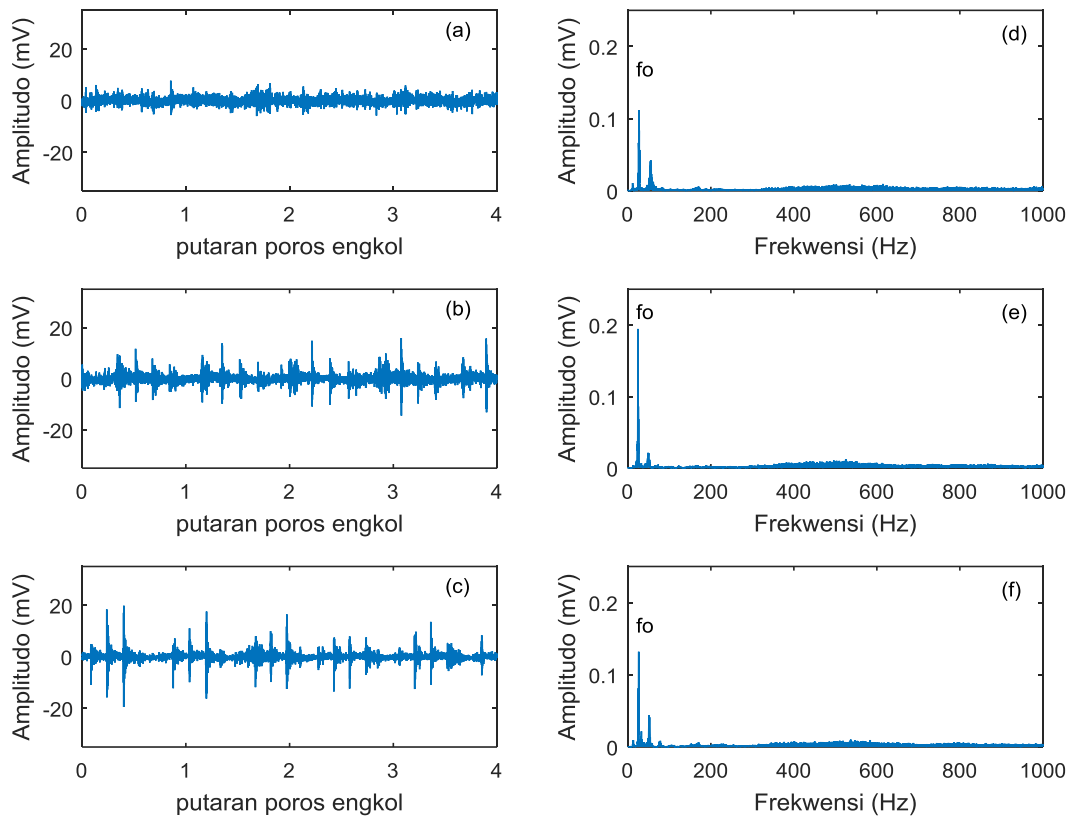

Gambar 3.1. Domain waktu bantalan (a) normal, (b) cacat 0,25 mm, (c) cacat 0,50 mm. Domain frekuensi bantalan (d) normal, (e) cacat 0,25 m, (f) cacat 0,50 mm. Kecepatan putaran poros engkol 1500 RPM

Table 3.1. Frekuensi Bantalan Cacat Lintasan Dalam (BPFI)

\begin{tabular}{ccc}
\hline Harmonik & \multicolumn{2}{c}{ BPFI hasil perhitungan } \\
\cline { 2 - 3 } & Kecepatan poros 1500 RPM & Kecepatan poros 2000 RPM \\
\hline 1xBPFI & $122,71 \mathrm{~Hz}$ & $163,46 \mathrm{~Hz}$ \\
\hline 2xBPFI & $245,45 \mathrm{~Hz}$ & $326,92 \mathrm{~Hz}$ \\
\hline 3xBPFI & $368,14 \mathrm{~Hz}$ & $490,38 \mathrm{~Hz}$ \\
\hline
\end{tabular}



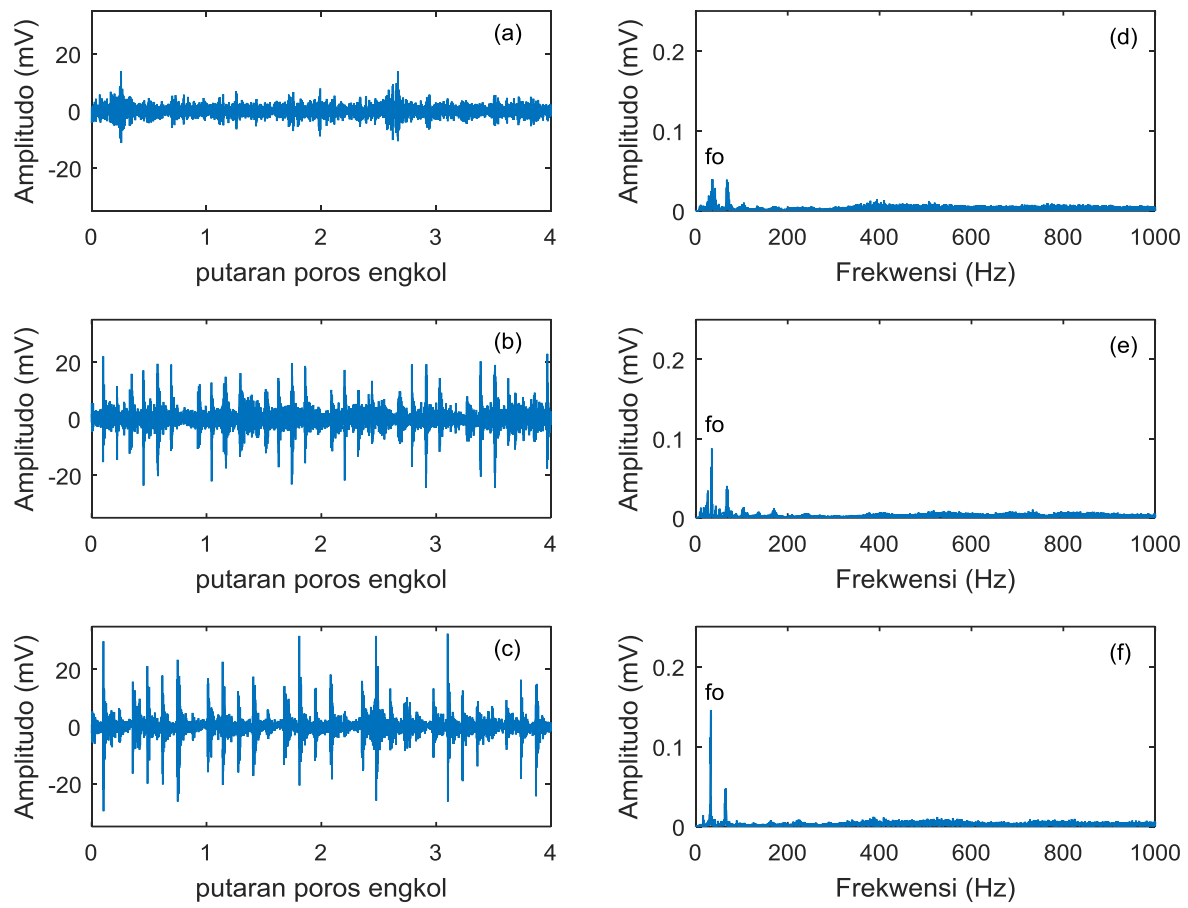

Gambar 3.2. Domain waktu bantalan (a) normal, (b) cacat 0,25 mm, (c) cacat 0,50 mm. Domain frekuensi bantalan (d) normal, (e) cacat 0,25 $\mathrm{m}$, (f) cacat 0,50 mm. Kecepatan putaran poros engkol 2000 RPM

Gambar 3.3 adalah spektrum envelope kondisi cacat $0,25 \mathrm{~mm}$ dan $0,50 \mathrm{~mm}$ pada kecepatan poros 1500 RPM. Spektrum envelope tersebut menunjukkan 3 harmonik frekuensi BPFI yaitu 1xBPFI sebesar 122,3 Hz dengan amplitudo 0,02374 mV, 2xBPFI sebesar $245,4 \mathrm{~Hz}$ amplitudo $0,01379 \mathrm{mV}$, dan 3xBPFI sebesar $365,4 \mathrm{~Hz}$ amplitudo sebesar $0,01068 \mathrm{mV}$. Kondisi tersebut menunjukkan tidak terdapat perbedaan frekuensi cacat antara kondisi cacat $0,25 \mathrm{~mm}$ dan $0,30 \mathrm{~mm}$ karena frekuensi cacat bukan fungsi dari besar cacat. Namun demikian, terdapat peningkatan amplitudo pada semua frekuensi cacat pada kondisi cacat $0,50 \mathrm{~mm}$ yang disebabkan oleh peningkatan energi impak pada kondisi cacat yang lebih besar.
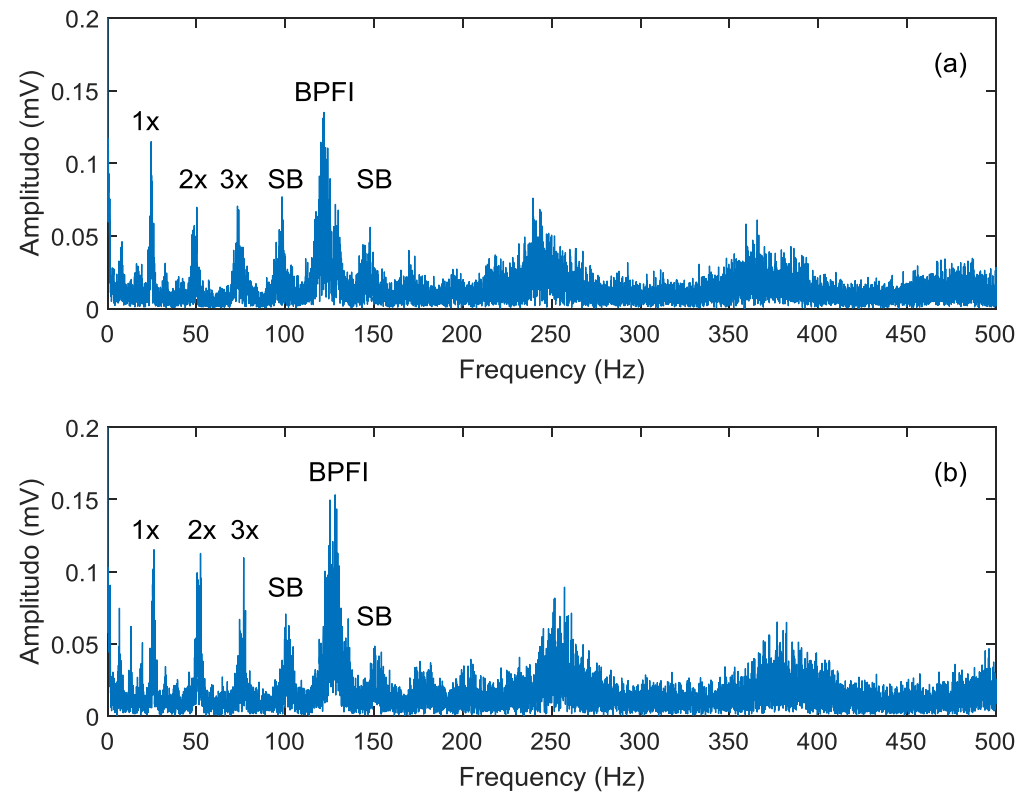

Gambar 3.3. Spektrum envelope (a) cacat 0,25 mm, (b) cacat 0,50 mm kecepatan poros 1500 RPM 
Selain frekuensi poros dan BPFI, spektrum envelope juga menunjukkan side band (SB) yang terletak pada sisi sebelah kiri dan kanan BPFI. Hal ini sesuai dengan teori yang menyatakan bahwa sinyal yang termodulasi akan menghasilkan side band pada spektrumnya. Jarak side band pada sisi samping kanan dan kiri dari frekuensi cacat bantalan pada kecepatan poros 1500 RPM adalah 1 kali kecepatan poros yaitu sebesar 25 $\mathrm{Hz}$. Side band terjadi akibat modulasi amplitudo sinyal getaran dari benturan cacat lintasan dalam dengan elemen gelinding bantalan. Cacat lintasan dalam bergerak keluar dan masuk loading zone. Ketika cacat lintasan masuk loading zone akan menghasilkan amplitudo lebih tinggi dibandingkan ketika keluar dari loading zone. Hal ini mengakibatkan tinggi amplitudo pada domain waktu "berayun" naik-turun yang disebut amplitude modulation (AM). Cacat bantalan lintasan dalam adalah salah satu tipe cacat bantalan yang menghasilkan modulasi amplitudo pada domain waktu.

Gambar 3.4 (a) dan (b) berturut-turut adalah spektrum envelope cacat 0,25 mm dan 0,50 pada kecepatan poros 2000 RPM. Terlihat jelas frekuensi 1 XBPFI sebesar $163,3 \mathrm{~Hz}$ dan dengan amplitudo $0,0283 \mathrm{mV}, 2 x B P F I$ sebesar $326,6 \mathrm{~Hz}$ dengan amplitudo 0,01728 $\mathrm{mV}$, dan 3xBPFI sebesar 490,9 Hz dengan amplitudo 0,007387 mV. Sama dengan spektrum envelope pada kecepatan poros 1500 RPM pada Gambar 3.3, Gambar 3.4 pada kecepatan poros 2000 RPM juga menunjukkan amplitudo tinggi pada frekuensi poros dan BPFI beserta harmoniknya. Dapat diamati dengan jelas bahwa amplitudo pada spektrum di Gambar 3.4 secara umum lebih tinggi dibandingkan dengan spektrum di Gambar 3.3. Peningkatan tinggi amplitudo disebabkan oleh energi benturan antara lokasi cacat dan elemen gelinding semakin tinggi dengan semakin tingginya kecepatan poros.

Side band juga terlihat jelas pada Gambar 3.4 dengan amplitudo lebih tinggi dibandingkan dengan spektrum di Gambar 3.3. Demikian juga, amplitudo side band teramati lebih tinggi pada cacat $0,50 \mathrm{~mm}$ dibandingkan dengan cacat $0,25 \mathrm{~mm}$. Peningkatan tinggi amplitudo side band mengindikasikan impak yang besar pada bantalan dan menunjukkan level kerusakan yang meningkat. Jarak side band ke BPFI teramati sebesar $33 \mathrm{~Hz}$ yang merupakan kecepatan poros.
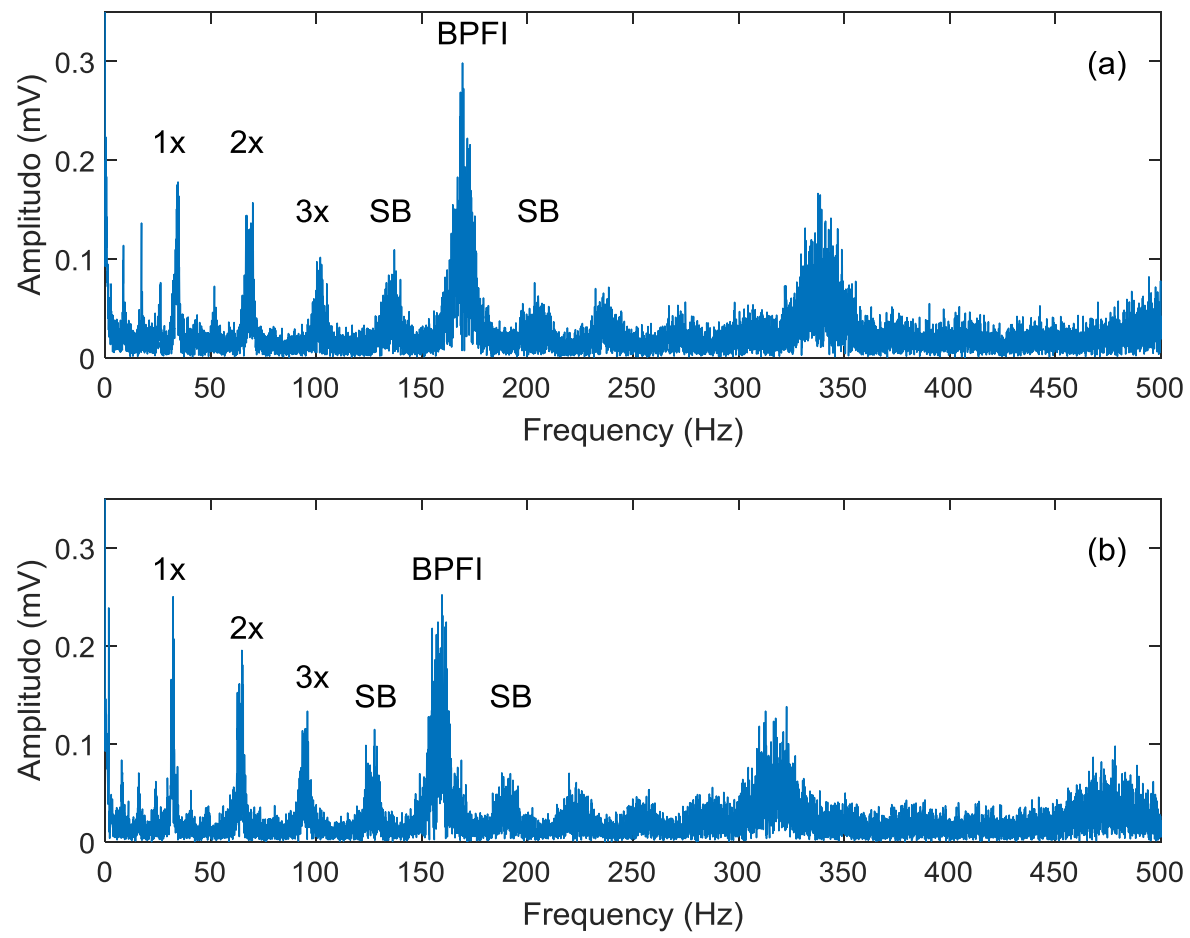

Gambar 3.4. Spektrum envelope (a) cacat 0,25 mm, (b) cacat 0,50 $\mathrm{mm}$ kecepatan poros 2000 RPM

Spektrum envelope menunjukkan amplitudo tinggi pada frekuensi cacat bantalan yang mudah diamati dibandingkan dengan yang ditunjukkan pada spektrum. Analisis spektrum 
sering tidak berhasil mendeteksi frekuensi cacat bantalan terutama pada kondisi cacat awal (early fault) atau pada kondisi ketika terdapat level getaran yang tinggi selain getaran berasal dari bantalan. Analisis envelope mampu mengeliminasi frekuensi getaran yang tidak berasal dari bantalan dengan menggunakan serangkaian prosedur pre-processing seperti high-pass filter dan transformasi Hilbert.

Spektrum envelope pada Gambar 3.3 dan 3.4 menunjukkan amplitudo tinggi pada frekuensi BPFI yang tidak teramati pada spektrum pada Gambar 3.1 dan 3.2. Dapat diamati pula pada Gambar 3.1 dan 3.2 bahwa ukuran cacat dan kecepatan poros tidak berpengaruh terhadap peningkatan amplitudo BPFI. Artinya, spektrum tidak sensitif untuk mendeteksi cacat pada bantalan untuk semua level cacat dan kecepatan poros pada mesin-mesin pembakaran dalam.

Hasil sebaliknya diperoleh pada spektrum envelope pada Gambar 3.3 dan 3.4 bahwa amplitudo BPFI tampak jelas dan mudah diamati pada semua ukuran cacat dan kecepatan poros. Terlihat peningkatan amplitudo BPFI seiring dengan peningkatan level cacat dan kecepatan poros. Hasil ini sejalan dengan yang didapatkan oleh Kamiel dkk. [10]. Spektrum envelope mampu menampilkan BPFI dan side band yang tidak teramati pada spektrum sehingga spektrum envelope efektif untuk mendeteksi cacat bantalan pada mesin-mesin pembakaran dalam.

\section{KesimpULAN}

Mesin-mesin pembakaran-dalam menghasilkan background noise yang besar yang berasal dari ledakan di ruang bakar dan gerak translasi dan rotasi komponen-komponennya. Hal ini mengakibatkan sinyal getaran bantalan terbenam di dalam amplitudo tinggi komponen-komponen tersebut. Cacat bantalan menghasilkan frekuensi yang merupakan fungsi dari geometri dan kecepatan poros.

Spektrum tidak dapat menunjukkan BPFI sinyal getaran mesin pembakaran dalam pada semua level cacat dan kecepatan poros. Amplitudo tinggi hanya teramati pada frekuensi kecepatan poros tidak berpengaruh pada peningkatan level getaran dan kecepatan poros dengan amplitudo BPFI.

Spektrum envelope terbukti mampu menampilkan BPFI yang tidak terdeteksi oleh spektrum. Selain BPFI, frekuensi side band juga teramati dengan jelas bahwa tinggi amplitudo side band mengindikasikan level kerusakan. Teramati peningkatan tinggi amplitudo BPFI dan side band yang sejalan dengan peningkatan ukuran cacat dan kecepatan poros.

\section{Daftar Pustaka}

[1] I. Yani, Y. Resti, and F. Burlian, "Identification of bearing failure using signal vibrations," Journal of Physics: Conference Series, vol. 1007, no. 1, p. 012067, 2018.

[2] M. Kunli and W. Yunxin, "Fault diagnosis of rolling element bearing based on vibration frequency analysis," in 2011 Third International Conference on Measuring Technology and Mechatronics Automation, pp. 198-201, 2011.

[3] S. Liu, F. Gu, and A. Ball, "Detection of engine valve faults by vibration signals measured on the cylinder head," Proceedings of the Institution of Mechanical Engineers, Part D: Journal of Automobile Engineering, vol. 220, no. 3, pp. 379-386, 2006.

[4] Y.-C. Choi and Y.-H. Kim, "Fault detection in a ball bearing system using minimum variance cepstrum," Measurement Science and Technology, vol. 18, no. 5, pp. 14331440, 2007.

[5] A. Tiwari and R. Jatola, "Fault detection in bearing using envelope analysis," Indian Journal Of Research, vol. 3, no. 5, pp. 75-78, 2013.

[6] D. Hochmann and E. Bechhoefer, "Envelope bearing analysis: theory and practice," in 2005 IEEE Aerospace Conference, pp. 3658-3666, 2005.

[7] B. Betea, P. Dobra, M.-C. Gherman, and L. Tomesc, "Comparison between envelope detection methods for bearing defects diagnose," IFAC Proceedings Volumes, vol. 46, no. 6, pp. 137-142, 2013. 
[8] D. Kateris, D. Moshou, X.-E. Pantazi, I. Gravalos, N. Sawalhi, and S. Loutridis, "A machine learning approach for the condition monitoring of rotating machinery," Journal of Mechanical Science and Technology, vol. 28, no. 1, pp. 61-71, 2014.

[9] C. Z. Tan and M. S. Leong, "An experimental study of cavitation detection in a centrifugal pump using envelope analysis," Journal of System Design and Dynamics, vol. 2, no. 1, pp. 274-285, 2008.

[10] B. P. Kamiel, M. Mulyani, and S. Sunardi, "Deteksi cacat bantalan bola pada pompa sentrifugal menggunakan spektrum getaran," Semesta Teknika, vol. 20, no. 2, pp. 204215, 2017. 